\title{
Climate Variability Concerns for the Future of Coffee in India : An Exploratory Study
}

\author{
Chengappa P.G. ${ }^{1}$, Devika C.M. ${ }^{2}$
${ }^{1}$ ICAR National Professor, Institute for Social and Economic Change (ISEC), Dr. VKRV Rao Road, Nagarabhavi, Bengaluru , India.
${ }^{2}$ Research Associate, Institute for Social and Economic Change (ISEC)

\begin{abstract}
This paper draws attention to the growing concern of climate variability affecting coffee production in India dominated by small holders. Climate related studies across coffee producing areas around the world have encapsulated the significant impacts on coffee physiology and thereupon production and yield. Specifically, choosing Kodagu district, the largest coffee growing district in India as the study area, the climate variability is assessed by analysing recorded climatic data over the last 33 years. The results revealed a marginal decrease in total rainfall and high monthly variability, rising temperatures and declining relative humidity levels that is likely to impact coffee production given the decreasing yields in the region witnessed at the macro as well as micro level. We concluded the paper by identifying adaptation and mitigation potential measures from existing and altered management practices by the coffee growers, government initiatives and alternate incomes based on interviews with coffee growers.
\end{abstract}

Keywords-Climate, Coffee, IPCC.

\section{INTRODUCTION}

The impacts from climate change are already widespread and the consequences have been witnessed all around the world (IPCC working group, $\mathrm{V}^{\text {th }}$ Assessment Report 2014) . The assessment on impacts, adaptation and vulnerability predicts that flora faces the highest risk that results in a systematic decline of crop production system and threatening livelihoods. India is among the countries most affected by climate change according to the 2015 Global Climate Risk Index (Kreft et al. 2014) and in particular the southern States (Arumugam et al. 2014) where coffee is grown. The magnitude of the impact will be multifold given that Indian agriculture contributes 13.9 percent to the country's GDP (Agricultural Statistics, 2014, GoI), supports 600 million people directly or indirectly and accounts for 14.17 per cent of total exports.

Coffee is the second largest traded commodity in the world next to petroleum products. The major producing countries are Brazil, Colombia, Vietnam, Indonesia, Mexico, India and Guatemala, whose economies earn considerable foreign exchange from the export of coffee. These countries are facing local and global impacts of climate change over the decades (Davis et al. 2012) as any fluctuations in temperature, rainfall, humidity, soil nutrients, moisture, sunlight, aeration and soil temperature could impact the growth and productivity of coffee plants. Using a crop suitability model based on downscaled climate scenarios for the coffee agro-forestry systems of Sierra Madre, South Mexico, Schroth et al. (2009) predicted a hotter climate, with increased frequency and intensity of hurricanes that are less favourable for quality coffee production. Craparo et al. (2015) predicted a drop in coffee production by 2060 in the northern Tanzanian highlands that grow Arabica variety of coffee due to the rise in minimum temperatures. The temperatures that are above the optimum, force rapid growth, early bearing and exhaustion and prolonged period of low yield. Similarly, Laderach et al. (2011) predicted that over time increasing temperatures shift suitable climates for coffee production to higher elevations. This alters the crop suitability, with small farmers at higher altitudes capable of increasing production of speciality grade coffees, while low altitude coffee tend to lose production due to increased temperatures. (Damatta et al. 2006). Also, increase in average temperature will increase infestation of certain pests (Girijashankar 2014) and diseases, while greater erosions from increased severity of rainfall reduces the fertility of the soil (FAO 2005). Across the world, extreme weather conditions in coffee growing regions has caused fluctuation in coffee yields (Joy 2004; Gay et al., 2006). These risks to coffee ecosystems accompanied by global economic and environmental changes can cause vulnerabilities at multiple levels and pose challenges for coffee growers to sustain a majority of small farms in India.

The major coffee growing regions of India are within the Western Ghats - a biodiversity hotspot, a landscape known for its diverse and indigneous flora and fauna. Here, coffee has been cultivated in a traditional agroforestry landscape under native and in recent times, exotic trees canopy cover intercropped with pepper. This practice has ensured the longevity of the farm, maintainenance of biodiversity while, simultaneously providing a host of ecosystem services. Over time, management strategies in these 
traditional coffee growing areas have been shifting towards monoculture to intensify cultivation systems and increase yields. However, monoculture coupled with erratic and extreme weather events pose risks to coffee growers in India as coffee phenology and yield heavily depend on natural ecosystem services and certain abiotic environmental conditions.

Currently, India's share of coffee forms 4.5 percent of the world production and trade, and over 70 per cent of the produce is exported earning a foreign exchange of $\$ 765.80$ million in 2013-14. Production has steadily risen and reached a peak of 3,27,000 MT in 2014-15 mainly from the increase in Robusta production. There are 3,00,390 coffee holdings in India and over 99.11 per cent of them are small i.e. below 10 hectares. This sector employs over 0.606 million people and 62.81 per cent of them being women, play a pivotal role in gender empowerment. The State of Karnataka accounts for 55.96 percent of the total bearing area and produces 69.3 percent of the total production (2013-14) spread over the districts of Chikmagalur, Hassan and Kodagu. (Coffee Statistics various issues, Coffee Board, India). The production of coffee has been fluctuating between 2,62,000 to 3,27,000 MT in the recent years, while the bearing area has been consistently increasing over the years. The yield of coffee in the recent years has witnessed a fall indicating that the increase in production is area led.

Given these probable impacts on agriculture, the focus in this paper is to study climate variability that is likely to affect coffee production and in turn the livelihood of coffee farmers in India. Following the introduction, the rest of the paper is organised as follows : we take a glimpse at the coffee scenario in India as well as Kodagu - the largest coffee growing district in India, also targeted as the study area for this exploratory study. The next section presents the analysis of selected climatic data in the district. Given the variability witnessed in the climatic data, we briefly explore the likely affects on coffee production in Kodagu. Finally, the interventions/management strategies that have evolved to adapt and mitigate the risks associated with climatic variability within the largest coffee growing district in India forms the conclusion of the paper.

\section{METHODOLOGY}

\subsection{Objectives}

From the above discussion, it is evident that there are potential vulnerabilities affecting coffee

production and particularly the productivity affecting the livelihood of small coffee growers. The risks that impact the sustenance of the coffee agro-forestry systems in the district have been analysed by Garcia et al (2010) and Abraham et al (2013). Given the variability in coffee production and the microclimatic environment required for sustenance of coffee within this changing landscape, the paper seeks to address the following specific objectives:

1. to analyse the variability of selected climatic factors in a predominantly coffee growing region and

2. to understand the coping and mitigation measures undertaken by the coffee growers in Kodagu district.

\subsection{Methodology}

The data on climatic variables was obtained from the Karnataka State Natural Disaster Managment Cell (KSNDMC) and data on Coffee production from the Coffee Board of India. Daily rainfall has been summed to obtain monthly and annual quantities, while the average of the daily maximum, minimum temperatures and relative humidity levels were taken to obtain the mean monthly, seasonal and annual figures for the three taluks of the district and the co-efficient of variation analysed to understand the relative variability. Monthly and seasonal values $^{1}$ of these bioclimatic indices are more important than yearly average values keeping in view the coffee phenology (Silva et al. 2004). The primary aim is to establish the trend in the district's climate, and in doing so, identify any climatic variables that influence coffee production in the district for the last 33 years (1980 - 2013). Apart from the district level analysis, the data on yield and weather maitained by 54 coffee growers at least for a period of ten years were analysed. The sample included 29 robusta and 25 arabica holdings.

\section{RESULTS AND DISCUSSION}

\subsection{Trend of climatic variables in Kodagu district}

This section presents a summary of trend estimates of maximum, minimum and diurnal temperature, monthly and annual rainfall, rainy days and relative humidity recorded in the district (Table I). The direction of the estimated trend of key climatic variables over the last three decades in Kodagu district revealed an upward movement across all temperature variables, a decrease in rainfall, particularly in the months of December, January, June and August.The relative humidity levels have also declined during December to May, and increased across the months of June to November.

odagu Seasons : Winter - January to March; Summer April and May; South West Monsoon - June to September and North East Monsoon - October to December based on Karnataka State's Agriculture Contingency Plan for Kodagu District. 
Table.I: Trend (monthly) of climatic variables in Kodagu District over 33 years (regressed with time)

\begin{tabular}{|l|l|l|l|l|l|l|}
\hline Month & $\begin{array}{l}\text { Maximum } \\
\text { Temperature }\end{array}$ & $\begin{array}{l}\text { Minimum } \\
\text { Temperature }\end{array}$ & $\begin{array}{l}\text { Diurnal } \\
\text { Temperature }\end{array}$ & $\begin{array}{l}\text { Total } \\
\text { Rainfall }\end{array}$ & Rainy Days & $\begin{array}{l}\text { Relative } \\
\text { Humidity }\end{array}$ \\
\hline Jan & $\uparrow$ & $\uparrow$ & $\uparrow$ & $\downarrow$ & $\downarrow$ & $\downarrow$ \\
\hline Feb & $\uparrow$ & $\uparrow$ & $\uparrow$ & $\uparrow$ & $\uparrow$ & $\downarrow$ \\
\hline Mar & $\uparrow$ & $\uparrow$ & $\uparrow$ & $\uparrow$ & $\uparrow$ & $\downarrow$ \\
\hline Apr & $\uparrow$ & $\uparrow$ & $\uparrow$ & $\uparrow$ & $\uparrow$ & $\downarrow$ \\
\hline May & $\uparrow$ & $\uparrow$ & $\uparrow$ & $\uparrow$ & $\uparrow$ & $\downarrow$ \\
\hline June & $\uparrow$ & $\uparrow$ & $\uparrow$ & $\downarrow$ & $\downarrow$ & $\uparrow$ \\
\hline Jul & $\uparrow$ & $\uparrow$ & $\uparrow$ & $\uparrow$ & $\uparrow$ & $\uparrow$ \\
\hline Aug & $\uparrow$ & $\uparrow$ & $\uparrow$ & $\downarrow$ & $\uparrow$ & $\uparrow$ \\
\hline Sept & $\uparrow$ & $\uparrow$ & $\uparrow$ & $\uparrow$ & $\uparrow$ \\
\hline Oct & $\uparrow$ & $\uparrow$ & $\downarrow$ & $\uparrow$ & $\uparrow$ & $\uparrow$ \\
\hline Nov & $\uparrow$ & $\uparrow$ & $\uparrow$ & $\uparrow$ & $\uparrow$ & $\uparrow$ \\
\hline Dec & $\uparrow$ & $\uparrow$ & $\uparrow$ & $\downarrow$ & $\downarrow$ & $\downarrow$ \\
\hline
\end{tabular}

Source: Data compiled from KSNDMC, Bangalore and Coffee Research Station, Chetalli, Kodagu

( Note : $\uparrow$ increase, $\downarrow$ decrease)

\subsection{Rainfall}

Our analysis of rainfall data revealed that the total rainfall in the district has decreased by 7.5 per cent. The average rainfall during the five year period (1980-85) was $2599.6 \mathrm{~mm}$ which decreased to $2402.5 \mathrm{~mm}$ during 2009-14 period. A close examination indicated that 70 per cent of the rainfall is received during the period June to August and so are the rainy days. The high variability in rainfall can be illustrated with an example; in July 2007, $1106 \mathrm{~mm}$ of rainfall was received over a span of 26 days which has not been witnessed in any previous years. In the year 2008, the South West monsoon was active only from 24th July 2008 indicating a delayed monsoon. High intensity rainfall as witnessed in 2012 (Chinappa 2012) has shown to cause soil saturation resulting in pre-mature fruit drop. Also, the heavy rainfall coupled with high humidity and hanging mist are conducive conditions that lead to coffee diseases such as incidence of black rot and stalk rot.

A close review of the data depicted in Fig.I shows irregular variation in total rainfall. The negative deviations from mean were more (19 years) than the positive deviations (14 years) depicting a decreased nature of total rainfall over the years. The winter rainfall has increased since 2006, after a continuous negative deviation from 1987 upto 2005. Summer and South-West (SW) monsoon rainfall deviations show more or less a cyclical pattern of variation, while the North-East (NE) monsoon indicated a smaller variation. Taluk wise analysis revealed that Madikeri and Somwarpet showing an increasing trend in total annual rainfall, while a decreasing trend was observed in Virajpet.

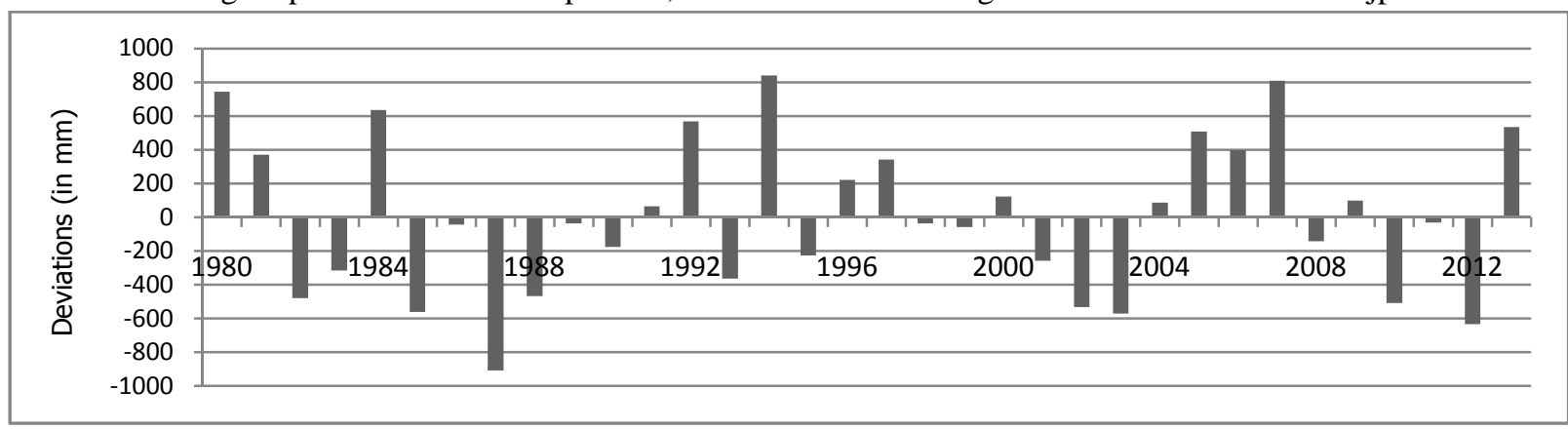

Fig. 1: Deviations of total rainfall from mean in Kodagu District (1980 to 2013)

source: Data compiled from KSNDMC, Bangalore

The coefficient of variation (CV) was calculated for each month across the study period to measure the volatility in rainfall distribution. The end of the NE monsoon and winter months recorded a high $\mathrm{CV}$, signifying increased relative variability of rainfall. It is lower in the months of August $(11.89 \%)$, June (12.21\%) and July (17.90\%) implying that the total monthly rainfall is stable across the SW monsoon season. While, the seasonal trend in rainfall recorded a www.ijeab.com decreasing trend during the SW monsoon period compared to the other three seasons. In terms of rainy days, data revealed a slight increase in the number of rainy days during all seasons. However, the dispersion during all seasons was high over the years. Relatively, the summer months witnessed extensive variations. The $\mathrm{CV}$ revealed high variability in the months of January (406.01\%), February (259.88\%) and December (153.19\%). A lower 
variability in rainy days was witnessed during the months of July $(14.45 \%)$ and August $(14.12 \%)$ respectively. The analysis clearly illustrated that the total rainfall has decreased and the erratic nature of rainfall increased in the recent years in Kodagu district.

\subsection{Temperature}

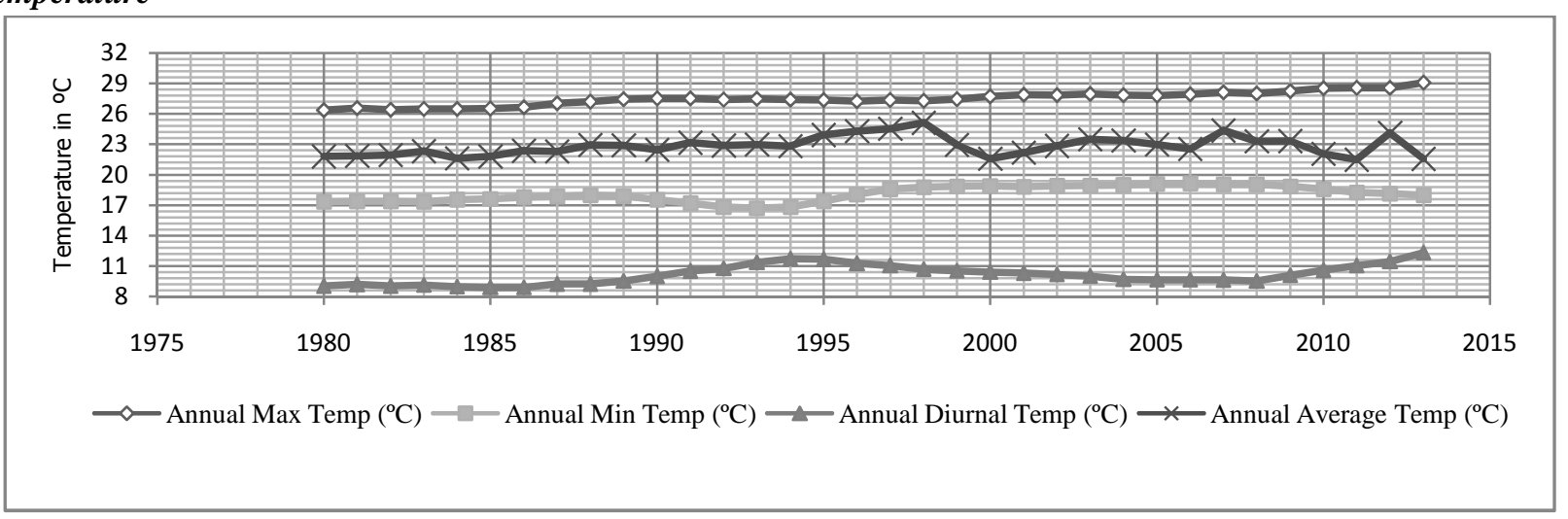

Fig. 2: Annual Average, Maximum, Minimum and Diurnal Temperature in Kodagu District (1980-2013) source: Data compiled from KSNDMC, Bangalore and Coffee Research Station, Chetalli, Kodagu
The maximum temperature over the study period showed an increase of $0.065{ }^{\circ} \mathrm{C}$. During the same period, the minimum temperature also increased by $0.0519^{\circ} \mathrm{C}$. As a result, the mean temperature of the district increased from $22.2{ }^{\circ} \mathrm{C}$ to $22.6{ }^{\circ} \mathrm{C}$. The annual mean diurnal temperature representing the difference between the daily maximum and minimum temperatures has also been increasing mainly due to increase in both mean maximum and minimum temperatures.The maximum monthly temperatures were higher in the months of March and April, while the minimum temperature was lower in the months of December and January. The diurnal temperature revealed high variation during the winter months of January and February while it was the lowest in July. The dispersion of minimum temperature was high during the winter season, particularly in December. Maximum and minimum temperatures across all seasons showed a marginal increase. The maximum temperature was higher during SW
The second key climatic factor that plays an important role in coffee ecosystems is temperature. The temperatures recorded for the last 33 years in Kodagu, revealed an increase in both maximum and minimum temperatures (Fig. II). monsoon season $\left(0.083^{\circ} \mathrm{C}\right)$. In case of minimum temperature, the increase was seen during the NE monsoon $\left(0.085^{\circ} \mathrm{C}\right)$.

\subsection{Relative Humidity ( $\mathrm{RH}$ )}

The third key climatic variable in this study is RH which is the amount of water vapour in the air at a specific temperature shown as a percentage. $\mathrm{RH}$ has a significant impact on the physiological processes of the coffee plant (DaMatta, 2007). The mean monthly level of relative humidity was low in the months of December and January, and highest in July. In terms of annual variability (Fig. III) all seasons showed a decreasing trend in the humidity levels. The $\mathrm{CV}$ of relative humidity was highest in December (11.66\%) and lowest during the month of July $(4.07 \%)$. Across the three seasons, except SW Monsoon, there is a decrease in the level of relative humidity. In winter and summer, the relative humidity fell by $0.25 \%$ and $0.062 \%$ respectively.

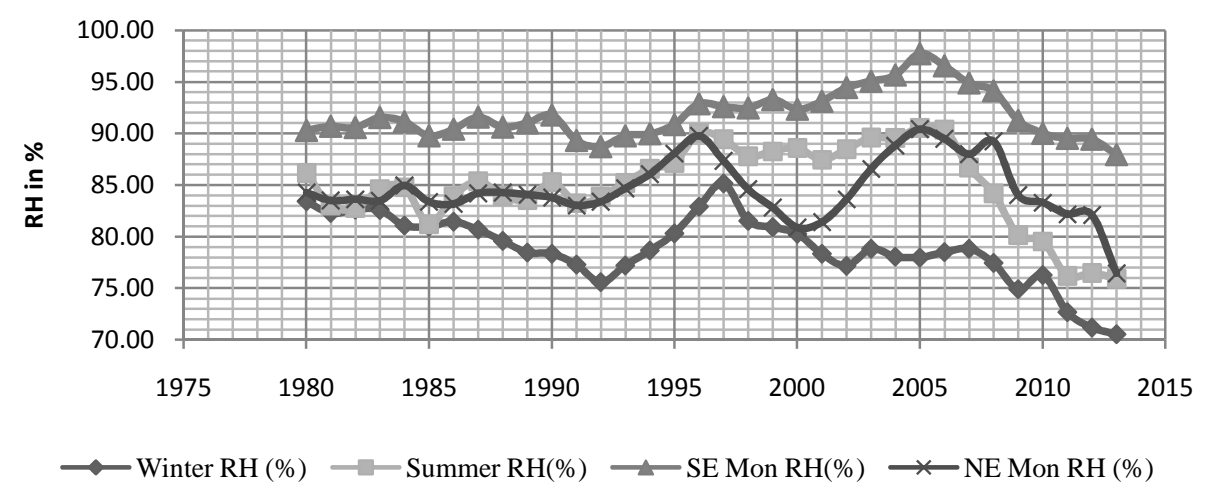

Fig.3: Annual mean of RH in Kodagu (1980 -2013)

source: Data compiled from KSNDMC, Bangalore and Coffee Research Station, Chetalli, Kodagu 
Based on the above trends in monthly and annual variation of these climatic factors over more than three decades, we postulated that these factors are effecting coffee crop management and thereupon its productivity. Accordingly, the crop-climate interaction was attempted in the following sections.

\section{CROP - CLIMATE INTERACTION}

Kodagu district lies on the eastern and western slopes of the Western Ghats in the State of Karnataka, where coffee is grown at an elevation of $750-1100 \mathrm{~m}$. Recorded coffee statistics shows an increasing trend in the coffee bearing area and production, while the yield depicted in Fig.IV indicates a continuous fall in Arabica mainly attributed to increased infestation of white stem borer. While the Robusta that is not susceptible to this pest shows a steady increase in yields in the district. If viewed decade-wise, there was a sharp rise in yield from 1980 to 1989, however, the yield decreased considerably in later years leading to low growth in production. The growth rates for production and yield for coffee in Kodagu stood at 3.52 per cent and 0.5 per cent respectively in the recent decade.

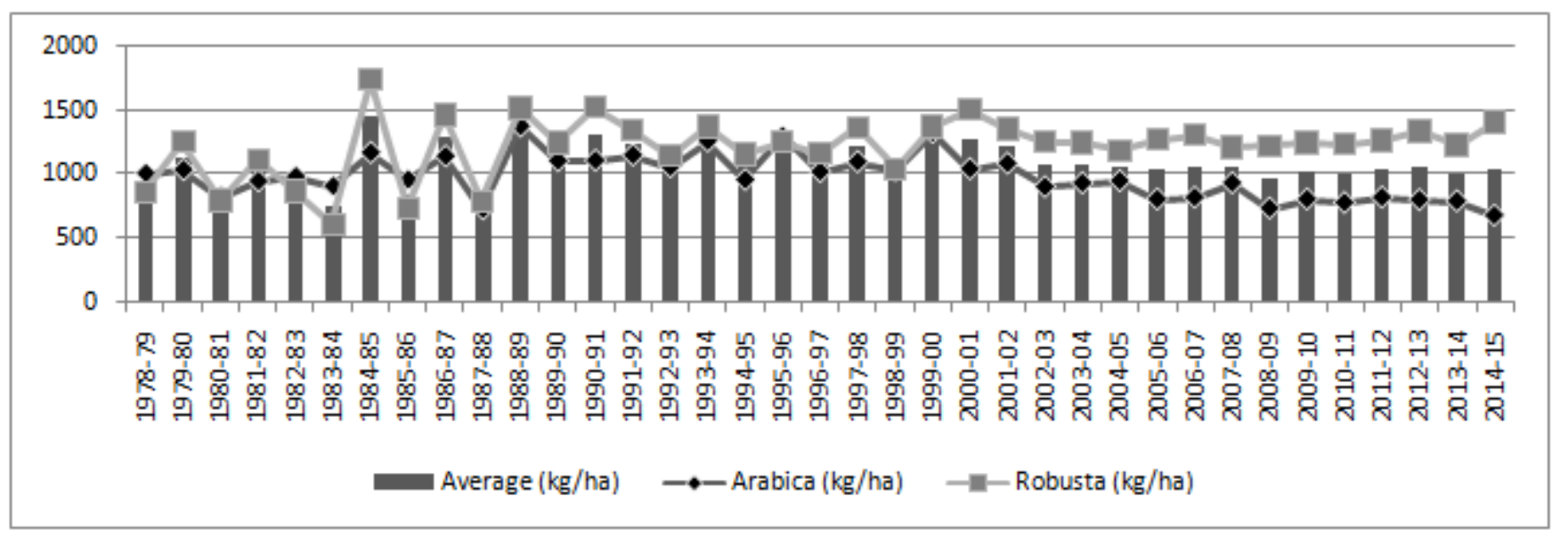

Fig. 4 : Total Yield, Arabica and Robusta yield in Kodagu District (kg/ha)

Source: Coffee Statistics, Coffee Board of India and Kodagu at a Glance (various issues)

The coffee crop production varies with inter-annual and long-term climate variability.It is highly sensitive to changes in seasonal rainfall and temperature (Bertrand et al, 2012). The anticipated impact of climate variability on coffee production is mostly based on existing climatecoffee production gradients. In India, the coffee ecosystems have been subject to variations in rainfall and temperature These influences have been broadly endorsed by coffee farmers and key informants interviewed during the course of the study ${ }^{2}$ in Kodagu (Chengappa et al, 2016). A majority of the Arabica holdings witnessed a negative growth in their coffee yield as compared to the positive growth of Robusta holdings in the last ten years reiterating our results of district level analysis. Among the arabica growers 64 per cent witnessed a fall in rainfall on their coffee holdings. While, 72 per cent of the robusta growers received less than average rainfall. Coffee growers indicated that the microclimate in their farms were affected when the temperature, relative humidity and solar radiation fluctuations increased significantly as shade cover decreased. The farmers explicitly pointed out that uneven distribution in rainfall and increasing day time temperature

\footnotetext{
${ }^{2}$ Interviews for study on perceptions of market and climate variability risks and adaptive responses by coffee farmers in Kodagu District
}

in the last 10 to 20 years affecting the biological processes resulting in low yields and high incidence of pest and diseases such as white stem borer ( Prabhu 2014). These problems are witnessed in coffee growing regions in Kodagu district leading to serious local ecological damages that can reach critical thresholds and have long-term implications on coffee production in the region.

during summer as the likely causes for increased berry dropping and higher incidence of pests and consequently leading to a reduction in their coffee yields witnessed in the recent years (Fig V). 


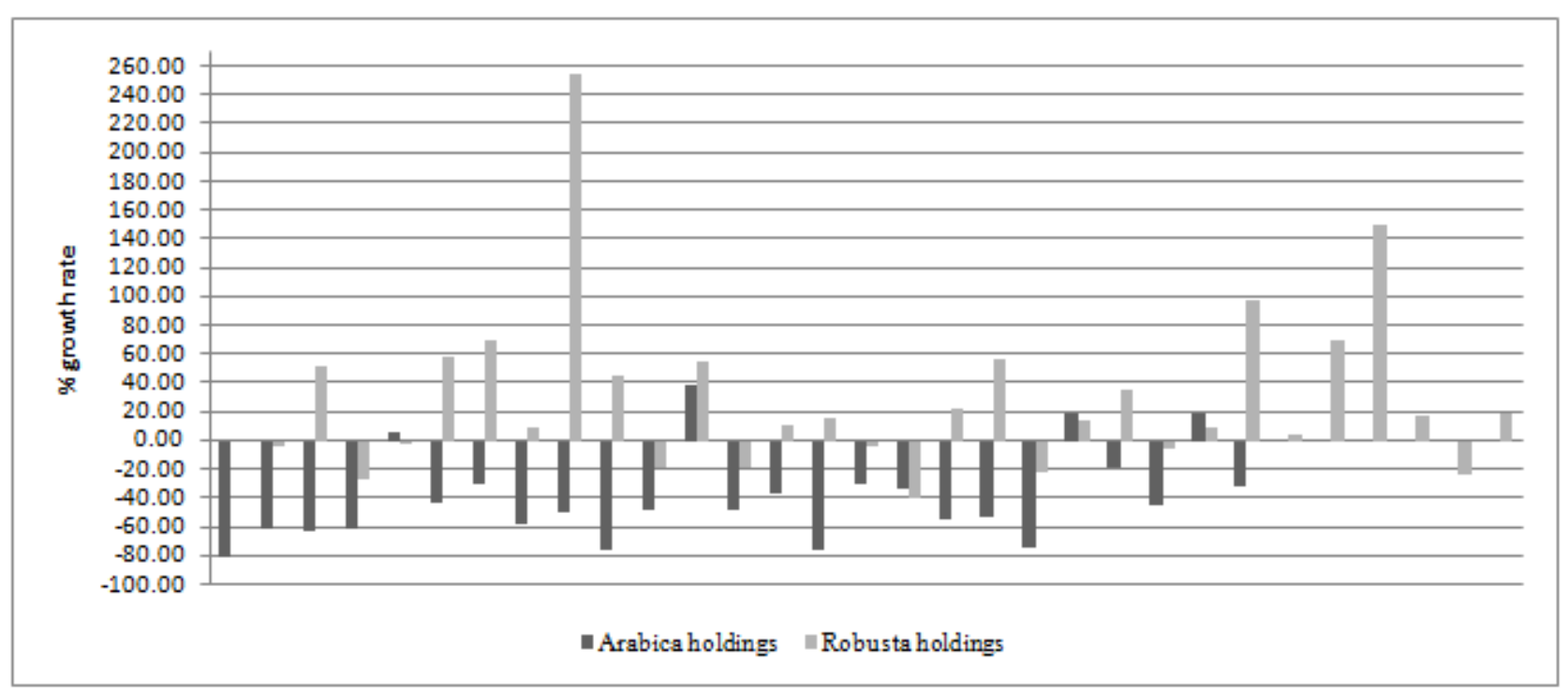

Fig.5: Yield of Robusta and Arabica coffee in sample holdings in Kodagu district source: compiled from primary data collected by the authors

\subsection{Coping measures undertaken by coffee growers in Kodagu district}

The analysis of rainfall, temperature and relative humidity over the 33 years have provided evidence on climate variability causing concern for coffee growers in Kodagu district. Rainfall data revealed a 7.5 per cent decrease in the amount of total rainfall, particularly SW Monsoon during the month of June, as a result of delayed monsoon. The rainy days, however increased mainly due to the rise in unseasonal rainfall. All the temperature variables showed a gradual rise while relative humidity witnessed a steep decline across seasons. Given these changing climatic conditions, management interventions are crucial in terms of adaptation decisions interwoven into the existing coffee production system. Coffee growers are increasingly adopting agronomic practices such as digging of new tanks and desilting/deepening of existing tanks, and trenching to conserve water, and deepening borewells to increase access to water for irrigation. Studies in the region show that coffee agroforestry systems have approximately 77-142 shade trees per acre with a Shannon's index of 2.37 compared to natural forests at 2.50 (Chethana et al. 2010; CAFNET 2011) that contribute to biodiversity conservation and carbon emissions reduction. Coffee growers have been increasing the number of harvestable shade trees as a risk adaptation strategy, that also creates a congenial micro climate environment. Consequently, shade regulation has become an important operation in coffee cultivation; continuance of agroforestry systems is suggested as an economically feasibly adaptive strategy (Nath et al. 2011). Growers have also gradually moved to a mix of organic and inorganic cultivation practices particularly to improve the soil fertility, given the frequent runoffs and erosion of top soil. Increase in pests and diseases as a result of erratic rainfall has led to low Arabica yields, resulting in several growers shifting to production of Robusta. The shift towards Robusta is quite evident at the macro level. The production of Arabica in Kodagu district in total production has declined from 25.62 per cent in 2000-01 to 15.25 per cent in 2014-15 and the share of Robusta has increased from 74.38 per cent to 84.75 per cent during the same period.

Crop diversification within a coffee agroforestry system has been in practice in Kodagu as a hedge aganist coffee yield variability risks. The commonly intercropped crops include pepper and coorg mandarin. Economic diversification has also been a coping measure, such as investing in financial instruments, real estate, commodity trading and construction related contract assignments. A few small and medium coffee growers have taken to ecotourism via homestays. Specifically, with the expectation that the observed current trends of increased climate variability and extreme weather events may continue in the future, reorienting current schemes with affordable weather indexed coffee insurance would provide enormous scope to mitigate loss in yield.

\section{CONCLUSION}

The climatic variabilty is evident in Kodagu, a predominantly coffee growing region in India, from the analyses of key climatic variables presented in this paper. Vast literature on the subject has also revealed that coffee growing regions will experience a decrease in climatic suitability for growing Arabica coffee similar to the 
evidence of decreasing yields witnessed by the sample growers in Kodagu. Interestingly, climate risks are not ranked high by coffee farmers as their priority concern as much as they do for market price volatility (Tucker et al. 2010, Chengappa et al, 2016). Options for coffee growers include adaptation through a series of agronomic interventions, alternative income sources and crop diversification. There are climate-smart agriculture strategies that can be emulated by coffee growers in India that also leverage public as well as private agencies in financing models that deliver climate resilience, mitigation gains and improve productivity. Some examples include climate-smart coffee in Ethiopia $^{3}$ and certified coffee producers in Oaxaca, Mexico ${ }^{4}$.

All things considered, there is a need to capture the indepth socio-ecological dimensions of climate change and coffee farmers' adaptive responses by applying narrative qualitative methods. This method would provide collective knowledge and experiences of coffee growers at the grass root level. As such, it offers to be participatory in design and highlights public deliberation in local adaptation policy-making (Paschen and Ison 2014) hitherto sparsely addressed in India's coffee environment. The agenda for forward looking research would be to identify the circumstances in which local actions in response to stress may have unforeseen ramifications. For e.g. decrease in carbon sequestration from shifting towards monoculture, indiscriminate use of groundwater for irrigation due to untimely annual rainfall.

\section{REFERENCES}

[1] Abraham R, Purushothaman S, Devy S (2013) Conservation and coffee production: creating synergies in Kodagu, Karnataka. In Livelihood Strategies in Southern India, Springer India. 89-107

[2] Arumugam S, Ashok KR, Kulshreshtha SN, Vellangany I, Govindasamy R (2014) Does Climate Variability Influence Crop Yield? - A Case study of Major Crops in Tamil Nadu. Agricultural Economics Research Review 27(1): 66- 71

[3] Bertrand B, Boulanger R, Dussert S, Ribeyre F, Berthiot L, Descroix F, Joët T (2012) Climatic factors directly impact the volatile organic compound fingerprint in green Arabica coffee bean as well as coffee beverage quality. Food chemistry 135(4): 25752583

\footnotetext{
${ }^{3}$ http://www.forest-

trends.org/documents/files/doc_3231.pdf accessed on 1210-2016

${ }^{4}$ http://www.rainforest-alliance.org/multimedia/oaxacacoffee-climate-short accessed on 12-10-2016
}

[4] CAFNET (2011). Final Report. Delhi: University of Agricultural Sciences, Bangalore (UASB); Central Coffee Research Institute, Coffee Board of India (CBI) and French Institute of Pondicherry (FIP). Retrieved from http://apps.ifpindia.org/ecrire/upload/eco_projects/CA FNET\%20India\%20Final\%20Report.pdf on 04 Sept 2016.

[5] Chengappa PG, Devika CM and Rudragouda (2016) Climate variability and mitigation: perceptions and strategies adopted by traditional coffee growers in India. Manuscript submitted for publication.

[6] Chethana AN, Nagaraj N, Chengappa PG, and Gracy CP (2010) Geographical Indications for Kodagu Coffee - A Socio-Economic Feasibility Analysis. Agricultural Economics Research Review 23: 97-103

[7] Chinappa J (2012) It's monsoon misery in Kodagu. http://www.thehindu.com/todays-paper/tp-features/tpdistrictplus/its-monsoon-misery-inkodagu/article3751933.ece accessed on 14-10-2016

[8] Craparo ACW, Van Asten PJA, Läderach P, Jassogne LTP, Grab SW (2015) Coffea arabica yields decline in Tanzania due to climate change: Global implications. Agricultural and Forest Meteorology 207: 1- 10

[9] DaMatta FM, Ramalho JDC (2006) Impacts of drought and temperature stress on coffee physiology and production: a review. Brazilian Journal of Plant Physiology 18(1): 55-81

[10] DaMatta FM, Ronchi CP, Maestri M, Barros RS (2007) Eco-physiology of coffee growth and production. Brazilian Journal of Plant Physiology 19(4): 485-510

[11]Davis AP, Gole TW, Baena S, Moat J (2012) The Impact of Climate Change on Indigenous Arabica Coffee (Coffea arabica): Predicting Future Trends and Identifying Priorities. PLoS ONE 7(11): e47981

[12]FAO (2005) Arabica Coffee manual for Lao-PDR. FAO Regional Office for Asia and $t$ he Pacific publication.

http://www.fao.org/docrep/008/ae939e/ae939e06.htm Accessed July 312015

[13] Garcia CA, Bhagwat SA, Ghazoul J, Nath CD, Nanaya KM, Kushalappa CG, Vaast P (2010) Biodiversity conservation in agricultural landscapes: challenges and opportunities of coffee agroforests in the Western Ghats, India. Conservation Biology 24(2): 479-488

[14] Gay C, Estrada F, Conde C, Eakin H, Villers L (2006) Potential impacts of climate change on agriculture: A case of study of coffee production in Veracruz, Mexico. Climatic Change 79(3-4): 259-288

[15] Girijashankar S (2014) Beetles high on Coffee. Down to Earth magazine. 
http://www.downtoearth.org.in/coverage/beetles-highon-coffee-45568 accessed on 17-09-2016

[16] IPCC (2014) In: Field CB, Barros VR, Dokken DJ, Mach KJ, Mastrandrea MD, Bilir TE, and Genova RC (Eds) Climate Change (2014): Impacts, Adaptation, and Vulnerability. Part A: Global and Sectoral Aspects. Contribution of Working Group II to the Fifth Assessment Report of the Intergovernmental Panel on Climate Change

[17] Kreft S, Eckstein D, Junghans L, Kerestan C, Hagen U (2014) Global Climate Risk Index 2015, Who suffers most from extreme weather events? Weatherrelated Loss Events in 2013 and 1994 to 2013. Briefing Paper. Germanwatch Berlin. Germany

[18] Laderach P, Lundy M, Jarvis A, Ramirez J, Portilla EP, Schepp K, Eitzinger A (2011) Predicted impact of climate change on coffee supply chains. In The Economic, Social and Political Elements of Climate Change, Springer Berlin Heidelberg. 703-723

[19] Nath CD, Pélissier R, Ramesh BR, Garcia C (2011) Promoting native trees in shade coffee plantations of southern India: comparison of growth rates with the exotic Grevillea robusta. Agroforestry Systems 83(2): 107-119

[20] Paschen JA, Ison R (2014) Narrative research in climate change adaptation - Exploring a complementary paradigm for research and governance. Research Policy 43(6): 1083-1092

[21] Prabhu N (2014) 3200ha of coffee plantation affected by stem borer pest in Karnataka. The Hindu. http://www.thehindu.com/news/national/karnataka/32 00-ha-of-coffee-plantation-affected-by-stem-borerpest-in-karnataka/article6648566.ece accessed on 112-2015

[22] Schroth G, Laderach P, Dempewolf J, Philpott S, Haggar J, Eakin H, Ramirez-Villegas J (2009) Towards a climate change adaptation strategy for coffee communities and ecosystems in the Sierra Madre de Chiapas, Mexico. Mitigation and Adaptation Strategies for Global Change 14(7): 605-625

[23] Tucker CM, Eakin H, Castellanos EJ (2010) Perceptions of risk and adaptation: Coffee producers, market shocks and extreme weather in Central America and Mexico. Global Environmental Change 20(1): 23-32

[24] Silva EA, DaMatta FM, Ducatti C, Regazzi AJ, Barros RS (2004) Seasonal changes in vegetative growth and photosynthesis of Arabica coffee trees. Field Crops Research 89(2): 349-357 